\title{
INTERNET DALAM BINGKAI DAKWAH ORGANISASI NAHDLATUL ULAMA
}

\author{
Muhammad Itsbatul Haq \\ UIN Syarif Hidayatullah Jakarta \\ mitsbatulhaq@gmail.com \\ Idris Ahmad Rifai, \\ Universitas Zaitunah, Tunisia \\ idrisrifai94@gmail.com
}

\begin{abstract}
This article focuses on the activities of the preaching of Nahdlatul Ulama as one of the religious organizations in Indonesia in the realm of the internet world. Nahdlatul Ulama (NU) is considered an Islamic organization that is anti-technological development. This assumption was born as a result of the wrong view of evaluating Nahdlatul Ulama as a pioneer of the traditionalist group due to the mismatch between religion and modernity. For Nahdlatul Ulama itself, the internet can be used as a useful medium for religion and can be used as a medium for deradicalization. The positive response of religion is seen in the use of the internet by Nahdlatul Ulama which is categorized into four forms of use, namely ideological, contextual, polemical and strategic use. All of these forms indicate that the internet as part of modernity can be used for the benefit and broadcast of religious information.
\end{abstract}

Kata Kunci: NU, Modernitas, Internet, Tradisionalisme.

\section{A. Pendahuluan}

Maraknya studi-studi tentang Islam dan kaitannya dengan dunia digital akhir-akhir ini seakan menjawab keraguan tentang tidak sepadannya agama dengan modernisasi. Keraguan pertama justru berasal dari dalam Islam sendiri. Menurut riset yang dilakukan Ali Kandari dan Ali Dashti di Arab Saudi, tanggapan-tanggapan negatif, sinis dan tidak jarang pula disertai penolakan dihembuskan oleh para ulama konservatif. Mereka beranggapan bahwa internet adalah produk modernitas yang disusupi unsur-unsur sekularisme dan dapat mengakibatkan agama kehilangan otoritas tradisionalnya ${ }^{1}$.

Di sisi lain, menurut pandangan pendukung teori sekularisasi seperti Armfield dan Holbert sebagaimana dikutip oleh Asep Iqbal, semakin relijius seseorang, ia akan semakin cenderung tidak menggunakan internet ${ }^{2}$. Hal tersebut didasarkan kepada argumen yang menyatakan bahwa internet adalah

1 Ali Kandari and Ali Dashti, (2014), Fatwa and the Internet A Study of the Influence of Muslim Religious Scholars on Internet Diffusion in Saudi Arabia, Promotheus: Critical Studies in Innovation, Vol.32, No.2, 127-144.

2 Asep Iqbal, (2013), Agama dan Adopsi Media baru: Penggunaan Internet oleh Gerakan Salafisme di Indonesia, Jurnal Komunikasi Indonesia, Vol. II, No. 2, Oktober 2013, $77-87$. 
sebuah teknologi yang dibangun di atas etos pandangan dunia sekuler. Hal senada juga disampaikan oleh Bockover dan Adamu yang menyatakan bahwa internet memiliki potensi berbahaya bagi agama karena dianggap membawa sistem nilai tertentu berupa kapitalisme ${ }^{3}$ dan westernisasi ${ }^{4}$.

Akibatnya, agama tidak bisa menempati posisi riilnya. Agama juga kehilangan penganutnya yang riil serta kesadaran kolektif mereka. Itu semua merupakan akibat dari pengalaman-pengalaman keagamaan yang didapatkan secara online ${ }^{5}$.

Karena sifatnya yang fleksibel dan sangat aman bagi anonimitas, internet juga dianggap berbahaya hingga sampai pada titik ia dianggap dapat melemahkan otoritas tradisional keagamaan. Dalam konteks global, internet dianggap menyediakan corong informasi alternatif yang melahirkan pemimpin-pemimpin agama baru yang kritis dan menantang legitimasi pemimpin agama tradisional dalam pengajaran keagamaan ${ }^{6}$

Dalam konteks Indonesia sendiri, penggunaan internet dan anonimitasnya sebagai media informasi keagamaan dikhawatirkan akan mengakibatkan anarki informasi. Sebuah ketidakteraturan informasi yang ada di internet karena kosongnya peran otoritas keagamaan dalam menjawab fungsi informasi dan melahirkan mufti, kiyai, ustadz dan mualim baru yang belum terbukti kredibilitasnya ${ }^{7}$. Bersamaan dengan hal tersebut, lahir pula istilah fatwa shopping yang menjadi fenomena meresahkan bagi otoritas keagamaan tradisional.

Kajian-kajian di atas secara global dapat dikatakan menggambarkan korelasi antara internet dan agama. Namun, lebih spesifik tulisan terakhir dari Nadirsyah Hosen, dapat dikatakan sebagai sebuah otokritik bagi organisasiorganisasi keagamaan Islam di Indonesia yang masing sangat tertinggal dalam mengadopsi dan mengadaptasi teknologi modern saat itu. Khususnya sebagai bagian dari upaya untuk menjalankan fungsi informasi dan mempertahankan eksistensi dan otoritasnya di tengah masyarakat modern.

Berdasarkan otokritik tersebut di atas, tulisan ini hadir untuk melihat sejauh mana reaksi otoritas keagamaan Islam, khususnya Nahdlatul Ulama (NU) di Indonesia dalam merespon internet sebagai media baru. Dengan berlandaskan pandangan bahwa internet dianggap mampu memberikan manfaat bagi Islam sebagai fasilitas bagi kepentingan dakwah dan corong informasi bagi para penganutnya.

${ }^{3}$ M. Bockover, (2003), Confucian values and the Internet: A Potential Conflict, Journal of Chinese Philosophy, Vol. 30. No. 2, 159-175.

${ }^{4}$ A.U. Adamu, (2002), Islam and the Internet. Diakses pada 19 Oktober 2018 dari http://www.kanoonline.com/publications/islam and the internet.htm.

${ }^{5}$ R. Schroeder \& N.Heather \& R.M. Lee, (1998), The Sacred and The Virtual: Religion in Multi User Virtual Reality, Journal of Computer Mediated Communication, Vol.4, No.2.

${ }^{6}$ E. Barker, (2005), Crossing the Boundary: New Challenges to Religious Authority and Control as a Consequence of Access to the Internet. Dalam M. Hojsgaard \& M. Warburg (Eds.), Religion and Cyberspace, London: Routledge, 67.85.

${ }^{7}$ Nadirsyah Hosen, (2008), Online Fatwa in Indonesia: From Fatwa Shopping to Googling a Kiai, Dalam Greg Fealy \& Sally White (Eds.), Expressing Islam: Religious Life and Politics in Indonesia, Singapore: Institute of Southeast Asian Studies, 159-173. 
Untuk itu, tulisan ini berusaha mengkaji Nahdlatul Ulama (NU) sebagai sebuah organisasi dan otoritas keagamaan di Indonesia serta responnya terhadap internet. Tulisan ini juga bermaksud untuk mengungkapkan bagaimana NU merespon internet yang mereka gunakan sebagai media penyebaran Islam yang toleran dan moderat.

Hal ini menjadi signifikansi kuat mengingat bahwa akhir-akhir ini muncul pula gerakan Islam kontemporer yang ultra konservatif seperti gerakan Salafi. Namun, uniknya, gerakan ini mampu merespon internet dengan baik dan memperlihatkan bahwa internet merupakan teknologi modern yang memiliki dampak positif bagi agama dan komunitas agama ${ }^{8}$.

Meskipun dianggap konservatif secara ideologi, gerakan salafi ini justru lebih dahulu mengadopsi teknologi internet. Isu-isu seperti "Digital Sword", "E-Jihad" hingga "Inter-Fada" menjadi bukti bahwa gerakan Salafi sudah lebih dahulu mengadopsi internet sebagai media mereka dalam menyebarkan ideologinya 9 .

Dengan upaya ini, tulisan ini diharapkan dapat berkontribusi bagi literatur yang mendukung adanya hubungan baik dan interaksi dinamis antara lembaga keagamaan di Indonesia dan internet di mana antara keduanya terjadi proses saling mempengaruhi ${ }^{10}$.

\section{B. Metodologi}

Pengumpulan data yang diperlukan untuk tulisan ini dilakukan dengan observasi online. Penelusuran langsung ke situs www.nu.or.id untuk mengunjungi laman situs official milik Nahdlatul Ulama. Pun ketika melacaknya dengan menggunakan kata kunci "NU Online", hasilnya memperlihatkan seluruh media platform yang digunakan oleh NU mulai dari laman situs resmi, beberapa berita dari kanal berita online, laman akun Facebook NU Online, akun Twitter resmi NU Online, akun Instagram resmi NU Online dan kanal video Youtube resmi NU Online.

Untuk kepentingan tulisan ini, analisis difokuskan pada situs resmi NU yaitu, www.nu.or.id. Pilihan ini didasarkan pada fakta bahwa situs ini menjadi sumber resmi informasi-informasi terkait NU. Selain itu, situs ini juga aktif dan banyak dikutip oleh laman-laman lain. Karena itu, hal ini dianggap memadai untuk dapat memberikan gambaran umum tentang respon Nahdlatul Ulama di Indonesia atas internet.

Isi situs (web content) yang berupa artikel-artikel yang diterbitkan oleh redaksi situs dan kontributor dikumpulkan dari situs NU Online di atas untuk mengungkap cara-cara yang dipakai oleh Nahdlatul Ulama dalam menggunakan media internet sebagai respon mereka atas teknologi informasi dan komunikasi. Postingan tersebut dianalisis untuk mengungkap topik, argument dan tipe respon yang dikandungnya. Metodologi yang digunakan

${ }^{8}$ Asep M. Iqbal, (2014), Internet, Identity and Islamic Movements: The Case of Salafism in Indonesia, Islamika Indonesiana, Vol. 1, No.1, 81-105.

${ }^{9}$ Lihat Gary R. Bunt, (2003), Islam in the Digital Age: E-Jihad, Online Fatwas and Cyber Islamic Environtments, London: Pluto Press.

${ }^{10}$ K. Nahon \& G. Barzilai, (2005), Cultured Technology. The Information Society, Vol. 21, 25-40. Lihat pula, H. Campbell, (2010), When Religion Meets New Media, London: Routledge. 
dalam analisis ini melibatkan penggunaan analisis tekstual dengan maksud mengungkap kategori-kategori dari penggunaan internet oleh NU. Dalam analisis ini, teks dipahami dalam bentuk artikel, laman, berita pada NU Online termasuk postingan dan gambar yang terdapat di situs tersebut ${ }^{11}$.

\section{Sejarah Nahdlatul Ulama}

Nahdlatul Ulama (atau yang biasa disebut dengan akronim: NU) adalah sebuah gerakan sosial keagamaan yang berdiri pada tahun 1926. Gerakan ini seringkali dianggap sebagai reaksi defensif terhadap berbagai aktifitas kelompok reformis di Indonesia ${ }^{12}$. Namun, NU sendiri ketika menjelaskan sejarah lahirnya, mengaitkannya dengan konteks global yang terjadi saat itu.

Kelahiran NU tidak bisa dipisahkan dari gerakan-gerakan "kebangkitan" yang ada sebelumnya. Di dalam situsnya, NU menyebutkan gerakan-gerakan seperti Nahdlatul Wathan (Kebangkitan Tanah Air), Tashwirul Afkar atau Nahdlatul Fikri

(Kebangkitan Pemikiran dan Nahdlatut Tujjar (Kebangkitan Kaum Saudagar) sebagai wadah pergerakan kaum santri untuk dapat memberikan kontribusi bagi semangat kemerdekaan pada masa penjajahan kolonialis ${ }^{13}$.

Pada tahun 1924, pasca kolapsnya kesultanan Turki Utsmani, umat muslim seluruh dunia termasuk Indonesia berencana untuk mengadakan sebuah kongres yang membicarakan tentang khilafah dan kepemimpinan muslim di dunia. Dari Nusantara sendiri, dibentuklah komite yang rencananya akan mengirimkan delegasi pada kongres tersebut beranggotakan Wondoamiseno, Soerjopranoto, H. Fachruddin dan KH. A. Wahab Hasbullah. Namun, kongres tersebut pada akhirnya ditunda.

Tidak berselang lama, muncullah ide dari Raja Ibn Saud yang ingin menerapkan azas tunggal madzhab Wahabi di Arab Saudi. Kendati mendapatkan sambutan hangat dari kaum modernis di Indonesia seperti Muhammadiyah di bawah pimpinan KH. Achmad Dahlan dan PSII di bawah pimpinan HOS. Tjokroaminoto. Ide ini justru mendapatkan penolakan dari kaum santri tradisionalis.

Karena memilih sikap yang berbeda, akhirnya kelompok santri tidak dilibatkan dalam kongres tahun 1925 di Yogyakarta dan KH. A Wahab Hasbullah sendiri akhirnya mendirikan sebuah komite sendiri yang kemudian dinamakan Komite Hijaz. Komite ini mendapatkan sambutan yang baik di kalangan para ulama dan santri Pada tanggal 31 Januari 1926 bertepatan dengan 16 Rajab 1334 Hijriah. Komite ini kemudan melaksanakan sebuah pertemuan di Surabaya yang dihadiri oleh KH. M. Hasyim Asy'ari, KH. M. Bisri Sanusi, KH. R. Asnawi, KH. Ma’shum, KH. Ridwan, KH. Nawawi,

${ }^{11}$ Karena sifat internet yang dinamis dan cepat berubah, pengumpulan data dalam tulisan ini hanya difokuskan pada posting-posting pada tahun 2018.

${ }^{12}$ Martin van Bruinessen, (2009), NU, Tradisi, Relasi-relasi Kuasa, Pencarian Wacana Baru, Terjemahan dari Traditionalist Muslims in A Modernizing World: The Nahdlatul Ulama and Indonesia's New Order Politics, Factional Conflict and The Search for A New Discourse,

Yogyakarta: LKiS, 13.

13 Artikel "Sejarah NU" diakses pada tanggal 20 Oktober 2018 dari https://www.nu.or.id/static/6/sejarah-nu. 
KH. Nahrawi, KH. Abdullah Ubaid, KH. Alwi Abdul Aziz, KH. A. Halim, KH. Ndoro Muntaha, KH. Dahlan Abdul Qohar dan KH. Abdullah Faqih ${ }^{14}$.

Pertemuan ini akhirnya menghasilkan beberapa keputusan penting yang diantaranya adalah pengutusan komite Hijaz untuk menemui Raja Ibn Saud dan menyampaikan pendapat para ulama Nusantara terkait pemberlakuan kebijakan madzhab tunggal di Arab Saudi. Utusan itu sendiri langsung diwakili oleh KH. A. Wahab Hasbullah dan Syaikh Ahmad Ghunaim AlMishry. Dan juga diterima langsung oleh Raja Ibn Saud yang kemudian berjanji untuk tetap menghormati kebebasan melaksanakan dan mengajarkan fiqih berdasarkan empat madzhab dan mengutamakan konsep ahlu sunnah wal jama'ah dalam jurisdiksi kerajaan Arab Saudi.

Selain itu, pertemuan tersebut menjadi cikal bakal berdirinya sebuah organisasi yang menjadi wadah para ulama dan santri dan kemudian dinamakan Nahdlatul Ulama. Nama dan struktur organisasi baru ini menunjukkan dominasi peran para ulama. Pengurusnya dibagi menjadi dua badan, yaitu Syuriyah atau badan keulamaan dan diisi oleh para ulama atau kiyai sepuh ${ }^{15}$. Serta Tanfidziyah atau badan eksekutif yang sebagian besar terdiri dari santri-santri muda. KH. M. Hasyim Asy'ari sebagai kiyai yang paling disegani dari kelompok pendiri kemudian terpilih sebagai Ketua Syuriyah dan diberi gelar Rais Akbar.

NU berdiri sebagai organisasi sosial keagamaan yang menyatakan anggaran dasarnya adalah kepatuhan pada ajaran madzhab yang merupakan hal pokok. Hal ini dinyatakan dalam Statuten dari Perkoempoelan Nahdlatoel Oelama di Surabaya, yang berbunyi:

Memegang dengan teguh pada salah satu dari madzhabnya Imam empat, yaitu Imam Muhammad bin Idris As-Syafi'i Imam Malik bin Anas, Imam Abu Hanifah An-Nu'man atau Imam Ahmad bin Hambal, dan mengerjakan apa saja yang menjadikan kemaslahatan agama Islam ${ }^{16}$.

\section{Nahdlatul Ulama: Sebuah Reaksi Anti-Modernitas ${ }^{17}$ ?}

\footnotetext{
${ }^{14}$ Dr. Endang Turmudi, MA (Eds.), (2004), Nahdlatul Ulama Ideology, Politics and the Formation of Khaira Ummah, Jakarta: PP. Lembaga Pendidikan Ma'arif NU, 20.

15 Istilah "ulama" dan "kiyai" sering diartikan sama, tetapi sebagaimana yang diterapkan di kalangan NU, keduanya mempunyai pengertian yang berbeda. Ulama khususnya merujuk kepada seorang kiyai yang memiliki pengetahuan yang memadai tentang berbagai cabang pengetahuan Islam atau yang merupakan cendekiawan di bidang keislaman. Kiyai sendiri merujuk kepada kategori yang lebih luas, yakni pemimpin dan pengajar/guru agama Islam. Hingga tahun 1970-an, hampir dapat dipastikan bahwa seorang kiyai adalah juga pemimpin pesantren.

${ }^{16}$ Choirul Anam, (1985), Pertumbuhan dan Perkembangan Nahdlatul Ulama, Solo: Jatayu, yang dikutip oleh Greg Fealy, (2007), dalam Ijtihad Politik Ulama Sejarah NU 19521967, Yogyakarta: LKiS. kembali

${ }^{17}$ Secara umum, modernism Islam dapat dimaknai dengan paham akan kebangkitan

Islam yang pernah terjadi di akhir abad Sembilan belas. Akan tetapi, kebanyakan cendekiawan Islam lebih suka membedakan antara "modernism" dan "pembaruan" (reformisme). Modernisme dianggap menekankan pada upaya pencarian relvansi terhadap masa kini bagi Islam sedangkan reformisme lebih terpusat pada upaya membersihkan iman dari berbagai bid'ah dan praktik-praktik yang dilarang.
} 
Sebagaimana yang dinyatakan oleh Martin van Bruinessen bahwa ajaran-ajaran muslim pembaru (reformis) dan modernis abad ke 19 dan 20 dapat dikatakan berlawanan dengan seluruh bangunan konsep kepercayaan dan amalan muslim tradisional ${ }^{18}$. Apabila kaum Muhammadiyah dan PSII dikatakan sebagai kalangan pembaharu atau modernis, maka dapat dikatakan pula bahwa Nahdlatul Ulama sebagai kaum tradisionalis.

Polarisasi antara modernitas dan tradisionalis ini menurut Greg Fealy, lahir akibat pendekatan historis yang didominasi oleh kaum modernis ${ }^{19}$. Pendekatan ini mulai digunakan pada awal 1950 hingga tahun 1970-an dan kemudian berubah menjadi pandangan konvensional bagi kalangan cendekiawan. Wacana yang disebut dominasi modernis ini bergerak dalam dua hal. Yang pertama, kaum modernis muslimlah yang dominan membentuk persepsi ilmiah dan jurnalistik tentang Islam Indonesia termasuk sikap negatif terhadap NU. Yang kedua, kaum modernis dan para peneliti Barat sama-sama telah terpukau oleh modernitas dan modernisasi yang mempengaruhi pandangan mereka terhadap budaya dan kepercayaan tradisional.

Akibatnya, NU sebagai organisasi muslim tradisionalis menjadi sasaran kritik kaum modernis dan pengamat Barat. Bagi kaum modernis, kaum tradisionalis dianggap sebagai mereka yang berkutat di permasalahan takhayul, tidak punya harapan, kuno dan tanpa berpikir mengekor kepada konsep dan praktik-praktik yang sudah ketinggalan jaman ${ }^{20}$.

Sampai di sini, bukan berarti NU tidak merespon tuntutan-tuntutan modernitas. Kalau ditilik secara sadar, kehadiran NU sendiri sebagai sebuah organisasi keagamaan dan sosial adalah bagian dari modernisasi itu sendiri. NU tidak bisa menghindari perkembangan realitas dan modernitas yang ada zaman kini. Untuk itu, NU mengembangkan sebuah konsep untuk menjawab tantangan pembaruan tanpa merusak tradisi, sesuai dengan prinsip almuhafazhatu 'ala al-qadim as-shalih wa al-akhdzu bi al-jadid al-ashlah berarti tetap memelihara nilai-nilai tradisional yang baik dan menggunakan nilai-nilai modern yang lebih baik.

Apabila dikaitkan dengan munculnya fenomena internet baru-baru ini, NU sendiri sudah mendapatkan otokritik dari cendikiawan mudanya sendiri. Dalam tulisannya yang berjudul Online Fatwa in Indonesia: From Fatwa Shopping to Googling a Kiai, Nadirsyah Hosen menyoroti upaya diseminasi fatwa-fatwa NU yang dihasilkan dalam forum Bahtsul Masail. Meski kritik itu juga ditujukan untuk dua organisasi besar lain, yakni Muhammadiyah dan Majelis Ulama Indonesia, Nadirsyah menyatakan bahwa ketiga organisasi besar ini harus bisa melakukan diseminasi fatwa secara lebih efektif di

18 Martin van Bruinessen, (2009), NU, Tradisi, Relasi-relasi Kuasa, Pencarian Wacana Baru, Terjemahan dari Traditionalist Muslims in A Modernizing World: The Nahdlatul Ulama and Indonesia's New Order Politics, Factional Conflict and The Search for A New Discourse, Yogyakarta: LKiS, 19.

${ }^{19}$ Greg Fealy, (2007), Ijtihad Politik Ulama Sejarah Nahdlatul Ulama 1952-1967, Yogyakarta: LKiS, 2.

${ }^{20}$ Greg Fealy, (2007), Ijtihad Politik Ulama Sejarah Nahdlatul Ulama 1952-1967, Yogyakarta: LKiS, 4. 
internet $^{21}$. Fasilitas cyber ini memungkinkan seorang muslim untuk berinteraksi dan mendapatkan akses informasi keislaman dengan mudah. Sekaligus mengantisipasi informasi-informasi yang lebih dulu dimanfaatkan oleh kaum radikal ${ }^{22}$.

\section{E. NU, Post-Tradisionalisme dan Culture Shift}

Sejalan dengan kritik Miftahuddin ${ }^{23}$ terhadap dikotomi modernis dan tradisionalis $^{24}$ yang menurutnya tidak relevan lagi untuk saat ini, penulis menganggap bahwa penyematan label tersebut pada dasarnya tidak memiliki landasan argumen yang kuat. Hal ini dibuktikan dengan rancunya penyematan modernitas bagi sebuah lembaga atau organisasi keagamaan hanya berlandaskan kepada paradigma ijtihad dan tajdid.

Miftahuddin berargumen bahwa saat ini sulit untuk mengatakan NU sebagai organisasi yang tradisionalis. Hal ini karena NU sejak awal berdirinya telah memanifestasikan pemikiran modern dalam konsep ideologinya yang inklusif, substansial, konvergen, manhaji dan bahkan cenderung liberal ${ }^{25}$.

Perjalanan NU sebagai sebuah salah satu dari beberapa organisasi tertua di Indonesia dan masih eksis hingga sekarang ${ }^{26}$ menggambarkan dinamika panjang yang dialaminya. Kendati dikenal sebagai tradisionalis, NU meletakkan tradisionalitasnya pada semangat untuk memelihara tradisi "Aswaja" (Ahl al-Sunnah wa al-Jamaah) yang menjadi ruh dari organisasi mereka ${ }^{27}$. Hal ini sejalan dengan jargon mereka yang terkenal "al-muhafazatu ala al-qadim al-salih wa al-akhdzu bi al-jadid al-aslah" (menjaga nilai-nilai tradisional yang relevan serta mengadopsi modernitas yang lebih baik).

Karena itulah, Greg Barton menyatakan, sebagaimana dikutip oleh Miftahuddin bahwa di dalam dinamikanya, tradisionalisme Islam (khususnya NU) pada akhirnya akan membukakan jalan bagi generasi neo modernis yang berwawasan pluralis, inklusif dan liberal. Dalam artian, melahirkan generasi pemikir-pemikir yang berwawasan ijtihad kontekstual dan berkomitmen

${ }^{21}$ Nadirsyah Hosen, (2008), Online Fatwa in Indonesia: From Fatwa Shopping to Googling a Kiai, Dalam Greg Fealy \& Sally White (Eds.), Expressing Islam: Religious Life and Politics in Indonesia, Singapore: Institute of Southeast Asian Studies, 161.

${ }_{22}$ Merlyna Lim, (2005), Islamic Radicalism and Anti-Americanism in Indonesia: The Role of the Internet, Policy Studies Series No.18, Washington DC: East West Center.

${ }^{23}$ Miftahuddin, (2010), Runtuhnya Dikotomi Tradisionalis dan Modernis: Menilik Dinamika Sejarah NU dan Muhammadiyah, Istoria: Jurnal Pendidikan dan Ilmu Sejarah, Vol. 7 No.

${ }^{24}$ Dalam hal ini, NU lebih sering disebut sebagai organisasi tradisionalis dan Muhammadiyah sebagai organisasi modern.

25 Miftahuddin, (2010), Runtuhnya Dikotomi Tradisionalis dan Modernis: Menilik Dinamika Sejarah NU dan Muhammadiyah, Istoria: Jurnal Pendidikan dan Ilmu Sejarah, Vol. 7 No.

26 Azyumardi Azra, (1999), Menuju Masyarakat Madani: Gagasan, Fakta dan Tantangan, Bandung: Rosdakarya, 46.

27 Azyumardi Azra, (2002), Liberalisasi Pemikiran NU, Kata Pengantar dalam Mujamil Qomar, (2002), NU "Liberal” dari Tradisionalisme Ahlusunnah ke Universalisme Islam, Bandung: Mizan, 141. 
untuk memadukan gaya berpikir Barat dan jiwa spiritualitas Islam $^{28}$. Dan inilah yang dimaksud dengan post tradisionalisme.

Prediksi Barton tersebut pada akhirnya dibuktikan lewat riset Rumadi dkk. yang mengkaji wacana post tradisionalisme Islam dalam komunitas NU. Riset tersebut menemukan generasi muda NU dengan cakrawala pemikiran baru yang lebih progresif ${ }^{29}$. Sebagai mana ditegaskan pula oleh Said Aqil Siradj bahwa NU yang selama ini dianggap tradisionalis dengan kultur pesantrennya justru menunjukkan gairah progresifitas dibandingkan dengan organisasi modern yang malah tampak stagnan dan resisten ${ }^{30}$.

Secara keseluruhan, fenomena post tradisional dalam NU bisa digambarkan dengan konsep Culture Shift yang digagas oleh Ronald Inglehart. Dalam bukunya yang berjudul Culture Shift in Advance Industrial Society, Inglehart mengatakan, "people's priorities tend to be shaped by the conditions of scarcity prevailing in their youth (the 'scarcity' and 'socialization' hypotheses), and that social change occurs as older generations are replaced by younger generations whose values are different". ${ }^{31}$

Progresifitas pemikiran generasi muda NU lahir sebagai respon terhadap kemajuan atau modernitas yang terjadi. Dan tentunya, hal tersebut menandakan bahwa NU sebagai sebuah organisasi tentunya tidak serta merta meninggalkan spirit tradisional mereka melainkan mempertahankannya secara substansial. Lebih dari itu, NU juga terbuka untuk mengadopsi produk modernitas yang dalam konteks tulisan ini mencakup penggunaan internet sebagai respon kebutuhan otoritas keagamaan di era teknologi baru-baru ini.

\section{F. NU dan Respon Terhadap Internet \\ Tentang Situs NU Online}

Situs yang dipilih untuk dikaji dalam tulisan ini adalah situs resmi Nahdlatul Ulama atau Suara Nahdlatul Ulama, www.nu.or.id. Dalam pelaksanaan redakturnya, situs ini diawasi dan disupervisi langsung oleh Ketua Umum Pengurus Besar Nahdlatul Ulama, Prof. Dr. KH. Said Aqil Sirodj, MA yang dicantumkan sebagai Dewan Penasehat Situs. Selain beliau, ada nama-nama lain sebagai Dewan Penasehat, seperti KH. Yahya C. Staquf, Drs. H. Imam Aziz, Dr. (HC). H. Helmy Faisal Zaini, Dr. H. Abdul Mun'im DZ dan H. Ulil Hadrawi, M.Hum.

Berlaku sebagai Pemimpin Umum dalam situs ini adalah Hari Usmayadi dan Direktur diisi oleh Mohamad Syafi' Alielha. Wakil Direktur diisi oleh H. Syaifullah Amin. Pemimpin Redaksi sendiri diisi oleh Ahmad

${ }^{28}$ Miftahuddin, (2010), Runtuhnya Dikotomi Tradisionalis dan Modernis: Menilik Dinamika Sejarah NU dan Muhammadiyah, Istoria: Jurnal Pendidikan dan Ilmu Sejarah, Vol. 7 No. 2, 14.

${ }^{29}$ Rumadi dkk, (2003), Post-Tradisionalisme Islam: Wacana Intelektualisme dalam Komunitas NU, Jurnal Istiqro, Vol. 2 No. 1, 200. Baca juga Anzar Abdullah dkk, (2018), Nahdlatul Ulama: from Traditionalist to Modernist, Proceeding of International Conference on Islam and Muslim Societies (ICONIS), 200.

${ }^{30}$ Said Aqil Siradj, (2003), NU, Tradisi dan Kebebasan Pikir, Kompas: Rabu, 29 Oktober 2003.

${ }^{31}$ Ronald Inglehart, (1990), Culture Shift in Advance Industrial Society, NJ: Princeton University Press, 1. 
Mukafi Niam dan jajaran redaksi yang berjumlah kurang lebih 28 orang. Selain staf redaksi, situs ini juga memiliki divisi IT \& Desain yang bertugas untuk memastikan operasional situs sesuai dengan mutu yang dituju. Selain itu, contributor yang berjumlah situs ini juga tersebar di berbagai wilayah di Indonesia ${ }^{32}$.

Situs ini didesain sebagai situs berbasis teks yang user friendly dengan desain warna putih sebagai latar tulisannya. Logo situs ini sendiri bertuliskan NU Online dengan kombinasi warna hijau pada tulisan NU dan hitam pada tulisan Online.

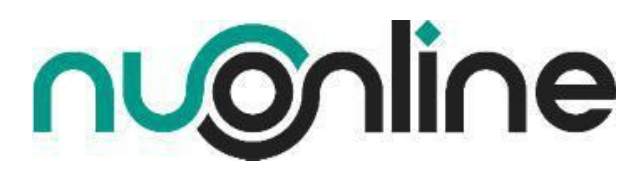

Situs ini menggunakan bahasa Indonesia dalam setiap artikelnya. Selain itu, situs ini juga menampilkan grafis-grafis menarik serta foto-foto actual dalam setiap postingan-nya. Pada laman utama, struktur situs ini dapat dibagi menjadi empat bagian. Pada bagian pertama, yaitu header. Di header, situs ini menampilkan logo NU Online. Di bagian kiri atas header terdapat pilihan laman berupa Tentang NU, Redaksi dan Download. Di sebelah kanan situs ini ada jaringan peramban (link) yang menghubungkan pembaca situs ke platform aplikasi lain seperti Facebook, Twitter, Instagram dan kanal Youtube resmi milik NU.

Masih di bagian header, tersedia menu-menu seperti Home, Warta, Fragmen, Keislaman, Wawancara, Opini, Seni Budaya, Taushiyah, Pendidikan Islam, Ekonomi, Mitra, Tokoh, Pustaka, Humor dan Video. Artikel-artikel yang dipublikasikan dalam situs ini merupakan tulisan-tulisan dari redaktur dan dari kontributor NU yang tersebar di berbagai wilayah di Indonesia.

\section{G. Penggunaan Ideologis Internet: Promosi Paham Ahlu Sunnah Wal Jama'ah}

Melalui situs ini, NU mempromosikan paham keagamaan yang menjadi pedoman utama dalam organisasi Nahdlatul Ulama. Hal tersebut dapat diperhatikan dari sebuah artikel yang menyebutkan bahwa NU menganut paham Ahlu Sunnah Wal Jama'ah. Paham ini, oleh NU diartikan sebagai pola pikir yang mengambil jalan tengah antara rasionalis ekstrim (ifrath aqli) dan skripturalis ekstrim (tafrith nashshiy).

Karena itu, bagi NU, sumber epistemologi keislaman tidak hanya dari Al-Qur'an dan Sunnah saja. Melainkan juga berasal dari kemampuan akal yang berdialektika dengan realitas empirik. Hal ini mereka tegaskan dengan menyebutkan bahwa cara berpikir semacam ini dirujuk dari pemikir terdahulu seperti, Abu Hasan Al-Asy'ari dan Abu Manshur Al-Maturidi di bidang teologi. Selain itu, mengikuti imam empat madzhab dalam bidang fiqih dan

\begin{tabular}{lllllll}
\hline 2 & Laman "Redaksi" diakses & tanggal & 20 & Oktober & 2018 & dari \\
https://www.nu.or.id/static/20/redaksi-nu.
\end{tabular}


bertasawuf sesuai dengan metode Al-Ghazali dan Junaid Al-Baghdadi yang merupakan integrasi antara prinsip-prinsip eksoteris dan nilai-nilai esoterik. ${ }^{33}$

Lewat situs ini pula, NU menolak segala bentuk paham radikal yang disisipkan dalam Islam. NU lebih mengedepankan prinsip-prinsip Islam wasathiyah atau Islam Moderat sebagai wacana yang mempersatukan masyarakat. Islam bukanlah agama yang mengusung arus keras, terburu-buru dalam mengkafirkan, membid'ahkan. Sebaliknya, Islam moderat yang diusung adalah Islam rahmatan lil 'alamin yang selaras dengan ajaran Islam yang diwariskan oleh Nabi Muhammad Saw. ${ }^{34}$

Selain menekankan pentingnya moderasi dalam beragama, lewat situs ini NU juga menekankan pemahaman-pemahaman keagamaan yang benar. Salah satunya lewat rubrik Ilmu Tauhid. Dalam rubrik ini, dapat ditemukan bahasan-bahasan kalam atau teologi khas mutakallimin klasik. Salah satu isu yang dikedepankan adalah aspek-aspek teologis tentang ketuhanan. Bahwa Tuhan berbeda dari makhluk-Nya, tiada yang menyerupai-Nya dan tidak pula manusia dapat menalar dzat-Nya. Berbeda dengan pandangan kaum salafi yang cenderung meyakini Tuhan dan memahami dzat-Nya secara tekstual dari ayat-ayat mutasyabihat. ${ }^{35}$

\section{H. Penggunaan Polemis Internet: Meluruskan Tuduhan Yang Salah}

NU juga menggunakan internet untuk meluruskan pandanganpandangan atau stigma negatif yang selama ini ditudingkan kepada mereka. Diantaranya tuduhan bahwa praktik yang selama ini dilakukan oleh nahdlyiyin adalah khurafat dan bid'ah.

Salah satu isu yang dituduhkan adalah amalan shalawat Nariyah yang dianggap melenceng dari ajaran Rasulullah Saw. Tuduhan ini didasarkan argumen umum bahwa apapun yang tidak dicontohkan oleh Rasulullah Saw adalah bid'ah yang tertolak. Namun yang lebih keras adalah tuduhan bahwa shalawat ini mengandung unsur-unsur syirik berdasarkan redaksi dari shalawat itu sendiri.

Dalam sebuah artikel, tuduhan-tuduhan tersebut dijawab dengan argument yang bernas. Didasarkan pada pengetahuan kebahasaan dan pemahaman yang dalam terhadap ilmu ushul fiqih, tuduhan-tuduhan itu dijawab sebagai sebuah kekeliruan. Pada dasarnya, dalam kacamata linguistik tidak ada unsur-unsur syirik yang terkandung dalam shalawat ini. Jawaban tersebut juga menekankan bahwa bahasa Arab dan bahasa Indonesia memiliki logika yang berbeda dan menjadi karakter khas masing-masing. Karena itu, redaksi Arab apabila dipahami tanpa meneliti struktur baku dapat mengakibatkan kepada pemahaman yang keliru. ${ }^{36}$

33 Artikel "Paham Keagamaan" diakses pada tanggal 22 Oktober 2018 dari https://www.nu.or.id/static/7/paham-keagamaan.

${ }^{34}$ Artikel "Penjelasan tentang Islam Moderat dan Islam Kaffah" diakses pada tanggal 22 Oktober 2018 dari https://www.nu.or.id/post/read/112208/penjelasan-tentang-islammoderat-dan-islam-kaffah.

35 Artikel "Kalimat Tauhid Saja Tak Cukup, Lima Aspek Ini Wajib Dipenuhi" diakses pada tanggal 22 Oktober 2018 dari https://islam.nu.or.id/post/read/104122/kalimattauhid-saja-tak-cukup-lima-aspek-ini-wajib-dipenuhi.

36 Dari artikel "Shalawat Nariyah, Tuduhan Syirik dan Ilmu Sharaf Dasar" diakses tanggal 22 Oktober 2018 dari https://islam.nu.or.id/post/read/72205/shalawat-nariyah- 
Selain permasalahan tadi, ditemukan juga jawaban atas permasalahan yang biasa menjadi perdebatan. Contohnya permasalahan tawassul. Bagi kalangan salafi, permasalahan tawassul ini menjadi polemik yang haram untuk diamalkan. Namun, sebaliknya, NU menjawab bahwa masalah tawassul adalah hal yang dibolehkan. Tentunya dengan kaidah-kaidah yang harus dipatuhi. Sebagaimana dicontohkan oleh Sahabat Umar bin Khattab ra. ${ }^{37}$

\section{Penggunaan Kontekstual Internet: Merespon Isu-Isu Kontemporer}

Sesuai dengan arahan dari Ketua Umum Pengurus Besar Nahdlatul Ulama (PBNU) Prof. Dr. KH. Said Aqil Siradj, MA yang mendorong santrisantri untuk bisa menyesuaikan diri terhadap perkembangan zaman dengan melakukan inovasi-inovasi strategis. NU Online dituntut untuk responsif memberikan inovasi-inovasi terbaru dengan menyuguhkan ide-ide kemajuan serta menjawab problematika kontemporer yang terjadi di masyarakat.

Dorongan ini juga disertai dengan seruan bagi santri untuk melek teknologi di era perkembangan digital. Santri dituntut untuk memainkan peranannya, khususnya di media sosial untuk membendung paham-paham radikal dan ekstrimis yang diakibatkan oleh orang-orang yang tidak memahami agama dengan benar namun unggul dalam masalah media sosial. Sebagaimana dikutip langsung, KH. Said Aqil Siradj menyatakan: "Kita yang paham agama, tapi ga ngisi konten medsos. Yang ngisi medsos malah yang ga ngerti agama, maka isinya caci maki, mengkafir-kafirkan orang karena yang mengisi konten medsos ga ngerti agama", 38

Karena itu, dalam sebuah menu laman khusus berjudul "Bahtsul Masail" NU berusaha menyajikan jawaban-jawaban dari pertanyaanpertanyaan yang dialamatkan kepada redaksi. Sedikit berbeda dari prosedur Bahtsul Masail yang umumnya dilakukan saat Munas dan Muktamar, Bahtsul Masail yang disajikan dalam situs ini merupakan jawaban dari para Kiyai atau Ulama NU yang memiliki kredibilitas dan kompetensi. Mereka diminta oleh Redaksi untuk membantu memberikan jawaban atas pertanyaanpertanyaan yang ada.

Diantara permasalahan kontemporer yang ditanyakan adalah hukum memakan daging wagyu $^{39}$ yang baru-baru ini menjadi tren kuliner di Indonesia. Jawaban dari permasalahan tersebut adalah bahwasanya daging tersebut halal untuk dikonsumsi apabila disembelih dengan jeda waktu

tuduhan-syirik-dan-ilmu-sharaf-dasar. Lihat juga artikel "Menjawab Penggugat Shalawat

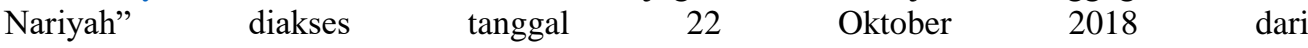
https://islam.nu.or.id/post/read/72195/menjawab-penggugat-shalawat-nariyah.

${ }^{37}$ Dari artikel "Ini Lafal Tawasul Umar bin Khattab saat Kemarau" diakses tanggal 22 Oktober 2018 dari https://islam.nu.or.id/post/read/111582/ini-lafal-tawasul-umar-binkhattab-saat-kemarau.

${ }^{38}$ Dari berita "Kiai Said: Santri Harus Inovatif, Cerdas dan Melek Teknologi” diakses tanggal Oktober 2018 dari https://www.nu.or.id/post/read/112487/kiai-said--santri-harusinovatif--cerdas--dan-melek-teknologi.

${ }^{39}$ Daging wagyu adalah daging sapi yang dibudidayakan di Jepang dengan perawatan khusus. Diantara perawatan terhadap sapi ini adalah dengan memberinya sake atau sejenis tuak yang dipercaya dapat menambah nafsu makan sapi. 
konsumsi tuak atau sake dan menjadi makruh hukumnya apabila pada masa penyembelihannya tetap diberi minum sake atau tuak ${ }^{40}$.

Permasalahan kontemporer lain yang dijawab dalam Bahtsul Masail ini adalah hukum imam berbeda lantai dengan makmum yang menggunakan proyektor $^{41}$. Selain itu ada juga pertanyaan kepada redaksi tentang hukum berbuka puasa lewat adzan Maghrib di televisi. ${ }^{42}$

\section{J. Penggunaan Strategis Internet : Media Informasi Organisasi}

Dengan jaringan pengurus cabang yang tersebar secara meluas di seluruh Indonesia bahkan hingga ke luar negeri. NU memiliki prakiraan jumlah basis pendukung yang mencapai lebih dari 40 juta orang dari beragam profesi di berbagai wilayah. Disertai dengan akhir-akhir ini terjadi pergeseran basis pendukung yang sejalan dengan pembangunan dan perkembangan urbanisasi $^{43}$.

Warga NU terlibat aktif dalam proses migrasi ke perkotaan untuk mengisi lini industri. Hal ini menuntut NU untuk bisa menyajikan informasiinformasi organisasi secara komprehensif dan jangkauan yang luas, worldwide. Karena itu, penggunaan internet sebagai media informasi organisasi menjadi sebuah keharusan tersendiri.

Yang pertama kali harus disampaikan sebagai informasi organisasi adalah tentang struktur kepengurusan organisasi itu sendiri. Pada laman Struktur disebutkan bahwa struktur organisasi NU terdiri dari beberapa lapisan struktural. Dimulai dari yang paling dasar yakni pengurus ranting di tingkat desa atau kelurahan, majelis wakil cabang di tingkat kecamatan, pengurus cabang di tingkat kabupaten/kota, pengurus wilayah di tingkat provinsi dan pengurus besar di tingkat pusat.

Lebih lanjut, masing-masing kepengurusan memiliki struktur kepengurusan sendiri yang terbentuk dari mustasyar (penasehat), syuriyah (pimpinan tertinggi) dan tanfidziyah (pelaksana harian). Namun, khusus untuk pengurus tingkat ranting, setiap kepengurusan terdiri dari syuriyah dan tanfidziyah. $^{44}$

Selain struktur kelembagaan sendiri, NU menampilkan lembagalembaga, badan otonom dan lajnah-lajnah dalam organisasinya. Namun, dalam tulisan ini hal tersebut tidak akan diuraikan secara terperinci karena bukan menjadi fokus yang dimaksud dalam bagian ini. Yang ingin difokuskan dalam tulisan ini adalah bagaimana NU mempublikasikan kegiatan

${ }^{40}$ Artikel "Hukum Mengonsumsi Daging Wagyu" diakses tanggal 22 Oktober 2018 dari https://islam.nu.or.id/post/read/108267/hukum-mengonsumsi-daging-wagyu.

${ }^{41}$ Artikel "Imam di Lantai Atas, Makmum Tahu Gerakan Imam lewat Proyektor" diakses tanggal 22 Oktober 2018 dari https://islam.nu.or.id/post/read/107593/imam-di-lantaiatas-makmum-tahu-gerakan-imam-lewat-proyektor.

42 Artikel "Hukum Berbuka Puasa Lewat Azan Maghrib di TV" diakses tanggal 22 Oktober 2018 darihttps://islam.nu.or.id/post/read/106209/hukum-berbuka-puasa-lewat-azanmaghrib-di-tv.

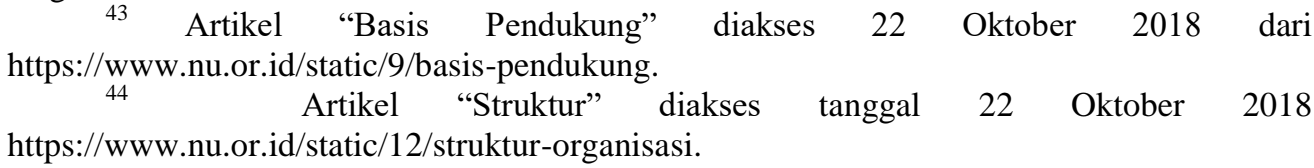


jejaringnya yang tersebar di seluruh Indonesia dan luar negeri melalui laman situs mereka.

Di mulai di Indonesia sendiri, pada tanggal 22 Oktober 2018 yang bertepatan dengan hari Santri Nasional, NU melakukan publikasi beragam kegiatan yang dilakukan pengurus wilayah dan pengurus cabangnya di seluruh Indonesia. Untuk skala Internasional sendiri, berbagai kegiatan pengurus cabang luar negeri juga mendapat publikasi yang memadai. Diantaranya publikasi kegiatan PCINU Jerman yang berencana mendirikan NU Center di Berlin sebagai bentuk internasionalisasi organisasi ${ }^{45}$. Selain itu, di Tiongkok juga melakukan kegiatan semarak hari Santri Nasional dengan mengadakan lomba baca kitab dan seminar online ${ }^{46}$. Lebih signifikan, GP Ansor sebagai badan otonom dalam organisasi NU diwartakan menemui Paus Fransiskus di Vatikan untuk membawa misi perdamaian Islam ${ }^{47}$.

Dalam konteks publikasi hasil-hasil Munas dan Muktamar serta produkproduk Bahtsul Masail, situs ini menyediakan laman tersendiri yaitu Download. ${ }^{48}$ Di dalamnya dapat ditemukan berbagai arsip-arsip organisasi yang terdiri dari produk hukum, amaliyah organisasi, buku-buku dan kitab dan atribut organisasi. Semuanya dapat diunduh dengan gratis dalam laman ini.

\section{K. Kesimpulan}

Beberapa bahasan tersebut di atas menunjukkan bahwa Nahdlatul Ulama merespon dengan baik kemajuan teknologi dan mengadaptasikan internet sebagai media informasi organisasi. Internet digunakan sebagai media informasi, komunikasi dan promosi identitas kolektif organisasinya.

Lebih dari itu, respon positif NU terhadap internet ditunjukkan dengan cara menggunakannya dalam beberapa bentuk penggunaan. Pertama, internet digunakan sebagai media penyebaran ideologi organisasi. Hal ini bisa diperhatikan dari konten-konten dan informasi yang disajikan di dalam situs NU Online.

Kedua, NU juga menggunakan internet sebagai media untuk meluruskan stigma-stigma negatif yang diarahkan kepadanya sebagai organisasi keagamaan tradisional. Lebih lanjut, dengan menggunakan internet, NU berusaha untuk mengakomodir modernisme sambil tetap terus berpegang teguh kepada wacana tradisional.

45 Artikel "PCINU Jerman Rencanakan Pendirian NU Center di Berlin" diakses tanggal 22 Oktober 2018 dari https://www.nu.or.id/post/read/112407/pcinu-jermanrencanakan-pendirian--nu-center--di-berlin.

${ }^{46}$ Artikel "Semarak Hari Santri di Tiongkok, Lomba Baca Kitab hingga Seminar

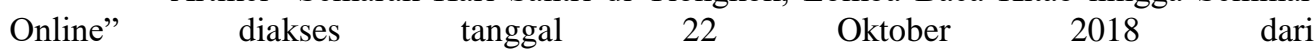
https://www.nu.or.id/post/read/111992/semarak-hari-santri-di-tiongkok--lomba-baca-kitabhingga-seminar-online.

${ }^{47}$ Artikel "Ketika GP Ansor Bawa Misi Perdamaian Islam ke Paus Fransiskus di Vatikan" diakses tanggal $22 \quad$ Oktober 2018 dari https://www.nu.or.id/post/read/111422/ketika-gp-ansor-bawa-misi-perdamaian-islam-kepaus-fransiskus-di-vatikan.

48 Laman "Dow
https://www.nu.or.id/archive. 
Ketiga, penggunaan internet dapat dimanfaatkan sebagai media untuk memberikan informasi-informasi keagamaan yang selama ini menjadi hal yang sulit dijangkau oleh masyarakat perkotaan pada khususnya. Beragam jawaban-jawaban masalah kontemporer disajikan di situs NU Online dan diampu oleh pakar-pakar yang kompeten.

Terakhir, NU memanfaatkan media internet sebagai alat untuk menjalin jejaringnya di tingkat Nasional dan Internasional. Hal ini ditunjukkan dengan informasi-informasi kegiatan yang dilakukan oleh pengurus-pengurus cabang baik itu di dalam maupun luar negeri.

Hal ini sekaligus menyangkal argumen yang menyatakan bahwa semakin relijius seseorang, ia semakin tidak tertarik untuk menggunakan internet. Begitu juga argumen yang menyatakan bahwa modernitas dapat menggerus nilai-nilai relijiusitas dalam diri seseorang. NU berhasil membuktikan bahwa tradisionalitas tidak selamanya bersifat konservatif terhadap modernitas. Organisasi seperti NU yang berlandaskan nilai-nilai tradisional agama, ternyata juga mampu mengadopsi dan mengadaptasikan teknologi internet sebagai media informasi organisasinya.

\section{DAFTAR PUSTAKA}

Adamu, A.U. (2002). Islam and the Internet. Diakses pada 19 Oktober 2018 dari

http://www.kanoonline.com/publications/islam_and_the internet.htm.

Anam, Choirul. (1985). Pertumbuhan dan Perkembangan Nahdlatul Ulama. Solo: Jatayu.

Anzar Abdullah dkk. (2018). Nahdlatul Ulama: from Traditionalist to Modernist. Proceeding of International Conference on Islam and Muslim Societies (ICONIS).

Azra, Azyumardi. (1999). Menuju Masyarakat Madani: Gagasan, Fakta dan Tantangan. Bandung: Rosdakarya.

Azra, Azyumardi. (2002). Liberalisasi Pemikiran NU. Kata Pengantar dalam Mujamil Qomar. (2002). NU "Liberal" dari Tradisionalisme Ahlusunnah ke Universalisme Islam. Bandung: Mizan.

Barker, E. (2005). Crossing the Boundary: New Challenges to Religious Authority and Control as a Consequence of Access to the Internet. Dalam M. Hojsgaard \& M. Warburg (Eds.). Religion and Cyberspace. London: Routledge.

Bockover, M. (2003). Confucian values and the Internet: A Potential Conflict. Journal of Chinese Philosophy. Vol. 30. No. 2.

Bunt, Gary R. (2003). Islam in the Digital Age: E-Jihad, Online Fatwas and Cyber Islamic Environtments. London: Pluto Press.

Bruinessen, Martin van. (2009). NU, Tradisi, Relasi-relasi Kuasa, Pencarian Wacana Baru. Terjemahan dari Traditionalist Muslims in A Modernizing World: The Nahdlatul Ulama and Indonesia's New Order Politics, Factional Conflict and

The Search for A New Discourse. Yogyakarta: LKiS. Campbell, H. (2010). When Religion Meets New Media. London: Routledge. 
Fealy, Greg. (2007). Ijtihad Politik Ulama Sejarah NU 1952-1967. Yogyakarta: LKiS.

Hosen, Nadirsyah. (2008). Online Fatwa in Indonesia: From Fatwa Shopping to Googling a Kiai. Dalam Greg Fealy \& Sally White (Eds.) . Expressing Islam: Religious Life and Politics in Indonesia. Singapore: Institute of Southeast Asian Studies.

Illar, Derek John. (2010). Cyber Fatwas and Classical Islamic Jurisprudence. The John Marshall Journal of Information Technology \& Privacy Law. Vol.27. No. 4. Summer 2010.

Inglehart, Ronald. (1990). Culture Shift in Advance Industrial Society. NJ: Princeton University Press.

Iqbal, Asep. (2013). Agama dan Adopsi Media baru: Penggunaan Internet oleh Gerakan Salafisme di Indonesia. Jurnal Komunikasi Indonesia. Vol. II. No. 2. Oktober 2013.

Iqbal, Asep M. (2014). Internet, Identity and Islamic Movements: The Case of Salafism in Indonesia. Islamika Indonesiana. Vol. 1. No.1.

Jati, Wasisto Raharjo. (2016). Cyberspace, Internet, dan Ruang Publik Baru: Aktivisme Online Politik Kelas Menengah Indonesia. Jurnal Pemikiran Sosiologi. Vol.3. No.1. Januari 2016.

Kandari, Ali and Ali Dashti. (2014). Fatwa and the Internet A Study of the Influence of Muslim Religious Scholars on Internet Diffusion in Saudi Arabia. Promotheus: Critical Studies in Innovation. Vol.32. No.2.

Lim, Merlyna. (2005). Islamic Radicalism and Anti-Americanism in Indonesia: The Role of the Internet. Policy Studies Series No.18. Washington DC: East West Center.

Miftahuddin. (2010). Runtuhnya Dikotomi Tradisionalis dan Modernis: Menilik Dinamika Sejarah NU dan Muhammadiyah. Istoria: Jurnal Pendidikan dan Ilmu Sejarah. Vol. 7 No. 2.

Nahon, K. \& G. Barzilai. (2005). Cultured Technology. The Information Society. Vol. 21.

Rumadi dkk. (2003). Post-Tradisionalisme Islam: Wacana Intelektualisme dalam Komunitas NU. Jurnal Istiqro. Vol. 2 No. 1.

Siradj, Said Aqil. (2003). NU, Tradisi dan Kebebasan Pikir. Kompas: Rabu, 29 Oktober 2003.

Schroeder, R. \& N.Heather \& R.M. Lee. (1998). The Sacred and The Virtual: Religion in Multi User Virtual Reality. Journal of Computer Mediated Communication. Vol.4. No.2.

Situmorang, James R. (2012). Pemanfaatan Internet Sebagai New Media Dalam Bidang Politik, Bisnis, Pendidikan dan Sosial Budaya. Jurnal Administrasi Bisnis. Vol.8 No.1. 19.

Turmudi, Dr. Endang. MA. (Eds.). (2004). Nahdlatul Ulama Ideology, Politics and the Formation of Khaira Ummah. Jakarta: PP. Lembaga Pendidikan Ma'arif NU. 


\section{Artikel Internet}

Artikel "Sejarah NU" diakses pada tanggal 20 Oktober 2018 dari https://www.nu.or.id/static/6/sejarah-nu.

Artikel "Paham Keagamaan" diakses pada tanggal 22 Oktober 2018 dari https://www.nu.or.id/static/7/paham-keagamaan.

Artikel "Penjelasan tentang Islam Moderat dan Islam Kaffah" diakses pada tanggal Oktober 2018 dari https://www.nu.or.id/post/read/112208/penjelasan-tentang-islammoderat-dan-islam-kaffah.

Artikel "Kalimat Tauhid Saja Tak Cukup, Lima Aspek Ini Wajib Dipenuhi" diakses pada tanggal 22 Oktober 2018 dari https://islam.nu.or.id/post/read/104122/kalimat-tauhid-saja-tak-cukuplima-aspek-ini-wajib-dipenuhi.

Artikel "Shalawat Nariyah, Tuduhan Syirik dan Ilmu Sharaf Dasar" diakses tanggal Oktober 2018 dari https://islam.nu.or.id/post/read/72205/shalawat-nariyah-tuduhan-syirikdan-ilmu-sharaf-dasar.

Artikel "Menjawab Penggugat Shalawat Nariyah" diakses tanggal 22 Oktober 2018

dari https://islam.nu.or.id/post/read/72195/menjawab-penggugat-shalawatnariyah.

Artikel "Ini Lafal Tawasul Umar bin Khattab saat Kemarau" diakses tanggal 22 Oktober 2018 dari https://islam.nu.or.id/post/read/111582/ini-lafaltawasul-umar-bin-khattab-saat-kemarau.

Artikel "Hukum Mengonsumsi Daging Wagyu" diakses tanggal 22 Oktober 2018 dari https://islam.nu.or.id/post/read/108267/hukum-mengonsumsidaging-wagyu.

Artikel "Imam di Lantai Atas, Makmum Tahu Gerakan Imam lewat Proyektor" diakses tanggal 22 Oktober 2018 dari https://islam.nu.or.id/post/read/107593/imam-di-lantai-atas-makmumtahu-gerakan-imam-lewat-proyektor.

Artikel "Hukum Berbuka Puasa Lewat Azan Maghrib di TV" diakses tanggal 22 Oktober 2018 dari https://islam.nu.or.id/post/read/106209/hukumberbuka-puasa-lewat-azan-maghrib-di-tv.

Berita "Kiai Said: Santri Harus Inovatif, Cerdas dan Melek Teknologi" $\begin{array}{lllll}\text { diakses } & \text { tanggal } & 22 & \text { Oktober } & 2018\end{array}$ https://www.nu.or.id/post/read/112487/kiai-said--santri-harus-inovatif-cerdas--dan-melek-teknologi.

Berita "Santri Rawalini Tangerang Berbagi Telur untuk Warga" diakses tanggal 22 Oktober 2018 dari

https://www.nu.or.id/post/read/112515/santri-rawalini-tangerangberbagi-telur-untuk-warga.

Berita "Santri Pringsewu Luncurkan Program Tanam 20.000 Bibit Pohon Produktif" diakses tanggal 22 Oktober 2018 dari https://www.nu.or.id/post/read/112510/santri-pringsewu-luncurkanprogram-tanam-20-000-bibit-pohon-produktif. 
Berita "PCINU Jerman Rencanakan Pendirian NU Center di Berlin" diakses tanggal Oktober 2018 dari https://www.nu.or.id/post/read/112407/pcinu-jerman-rencanakanpendirian--nu-center--di-berlin.

Berita "Semarak Hari Santri di Tiongkok, Lomba Baca Kitab hingga Seminar Online" diakses tanggal 22 Oktober 2018 dari https://www.nu.or.id/post/read/111992/semarak-hari-santri-di-tiongkok- lomba-baca-kitab-hingga-seminar-online.

Berita "Ketika GP Ansor Bawa Misi Perdamaian Islam ke Paus Fransiskus di Vatikan" diakses tanggal 22 Oktober 2018 dari https://www.nu.or.id/post/read/111422/ketika-gp-ansor-bawa-misiperdamaian-islam-ke-paus-fransiskus-di-vatikan.

Laman "Basis Pendukung" diakses 22 Oktober 2018 dari https://www.nu.or.id/static/9/basis-pendukung.

Laman "Struktur" diakses tanggal 22 Oktober 2018 dari https://www.nu.or.id/static/12/struktur-organisasi.

Laman "Redaksi" diakses tanggal 20 Oktober 2018 dari https://www.nu.or.id/static/20/redaksi-nu.

Laman "Download" diakses tanggal 22 Oktober 2018 dari https://www.nu.or.id/archive. 